\title{
TV/Series
}

1 | 2012

Les Séries télévisées américaines contemporaines :

entre la fiction, les faits, et le réel

\section{Melding Fiction and Reality in HBO's Carnivàle}

Jean Du Verger

\section{(2) OpenEdition}

Journals

Electronic version

URL: http://journals.openedition.org/tvseries/1504

DOI: 10.4000/tvseries.1504

ISSN: 2266-0909

Publisher

GRIC - Groupe de recherche Identités et Cultures

\section{Electronic reference}

Jean Du Verger, " Melding Fiction and Reality in HBO's Carnivàle », TV/Series [Online], 1 | 2012, Online since 15 May 2012, connection on 19 April 2019. URL : http://journals.openedition.org/tvseries/1504 ; DOI : 10.4000/tvseries. 1504

\section{(c) $\oplus \Theta \Theta$}

TV/Series est mis à disposition selon les termes de la licence Creative Commons Attribution - Pas d'Utilisation Commerciale - Pas de Modification 4.0 International. 


\section{Melding fiction and reality in HBO's Carnivàle ${ }^{1}$}

Carnivàle, created by Daniel Knauf, portrays a travelling carnival wending its way through the Dust Bowl during the unsettled period of the Great Depression, while the overarching story depicts the epic battle between good and evil. The show was cancelled by HBO after two seasons (2003-2005) not only because viewing rates had dropped significantly but also for financial reasons. The present article explores how fiction and reality interact in the show's complex narrative pattern, which disrupts the formulaic structure of traditional TV series. The constant oscillation between both realms disorientates the viewers as they venture into a world where dreams and reality conflate, creating its own fictional reality, while the narrative's complex pattern and subtext induce greater involvement on the viewers' behalf as the unfolding story requires their complete attention in order to decipher its meaning. The fusion between history (the Dust Bowl and the Great Depression) and fiction enhances the viewer's sense of confusion. The numerous cultural, historical and geographical references create a blurred area located between fiction and reality.

"It's a carnival. Things are never what they seem." Clancy Brown (Brother Justin Crowe)

C arnivàle, created by Daniel Knauf and aired on HBO, ran for two seasons between September 14, 2003 and March 27, 2005. HBO's president Chris Albrecht decided, despite critical acclaim, to cancel the show at the end of the second season not only because the ratings had fallen but because of the production cost: each episode was running on a budget of approximately $\$ 3.5$ million. The decision resulted in angry fans besieging the network sending up to 50,000 emails $^{2}$ in one single weekend while TV Guide opined that HBO had merely acted like just any average TV network: "[f]or a network that brags, 'It's not TV. It's HBO', that was a real TV kind of thing to do 3 ".

Carnivàle is a dark and eerie period drama set in the United States during the Dust Bowl at the heart of the Great Depression of the 1930s. The show follows the uncanny errands of a nomadic sideshow from Oklahoma to California, while the overarching story depicts the

${ }^{1}$ This paper is an improved version of the one I gave during the Journées d'études: Séries d'élites, culture populaire: le cas $H B O$, organised by Sciences Po Paris and the University of Picardie, in Paris on 7 and 8 June 2010 and I would like to thank Marjolaine Boutet for her kind invitation. The Wikipedia article on Carnivàle proved of great help in my research not to mention Series Concept \& Background by Daniel Knauf, <http://www. harvardwood.org/resource/resmgr/hwp-pdfs/carnivale_pitch_document.pdf>, April 15, 2011.

2 “Carnivàle Fans Besiege HBO with E-mails", ZAP 2 it, zap2it.com, July 19, 2005

3 "TV Guide Weighs in on HBO's cancellation of Carnivàle", TV Guide, June 1, 2005 
epic battle between good - the young Ben Hawkins (Nick Stahl) - and evil - the Methodist preacher Brother Justin Crowe (Clancy Brown). The show's narrative structure was, as Daniel Knauf avers, "designed to operate on more than one level4" encouraging a new mode of viewer engagement 5 . Besides being melded into historical reality, the intricate subtext, which had been subtly woven into Carnivàle's plot, made it, at the time, one of the most disconcerting and abstruse shows on television since Twin Peaks (ABC, 1990-1991) ${ }^{6}$. The plot revolves around two parallel storylines, which slowly converge toward one another to conflate into one single plot during the show's last two episodes.

The purpose of this paper - while parsing out the web of subtextual references embedded in the narrative - will be to show how, through filmic strategies and narrative structures, the recurrent eruption of dreams and visions in the "narrative reality" constantly transgresses the limits between fiction and reality. I will then examine the way in which fiction is subtly enmeshed into the historical template of the Thirties, thus creating a world in which both realms collide.

\section{1. "When The Grapes Of Wrath meets David Lynch"}

I shall only examine here some of the most prominent features illustrating Carnivàle's highly complex narrative structure ${ }^{7}$ and which contribute to blurring the boundaries between fiction and reality. During the opening title sequence ${ }^{8}$ the viewer is literally drawn into the

\footnotetext{
4 “Dan Knauf Interview", The Bally, February 15, 2005, <http://www.Carnycom/bally/dan.html>, April 11, 2011.

5 See Henry Jenkins's book Fans, Bloggers and Gamers. Explore Participatory Culture, New York \& London, New York University Press, 2006. Henry Jenkins, who explores the concept of the active audience and fan culture notes that "[t]he past decade has seen a marked increase in the serialization of American television, the emergence of more complex appeals to program history, and the development of more intricate story arcs and cliffhangers. To some degree, these æsthetic shifts can be linked to new reception practices enabled by the home archiving of videos, net discussion lists, and web program guides", p. 145 .

${ }^{6}$ Discussing Twin Peaks, Mark Jancovitch and James Lyons suggest in the introduction of their study on "quality television" that the show "was instrumental in provoking television producers to rethink their relationship to fans and cult audiences" thus underlining the growing importance of interplay in recent television shows. Mark Jancovitch \& James Lyons, Quality Popular Television. Cult TV, the Industry and Fans, London, B.F.I. Publishing, 2003, p. 2.

7 See Jason Mittell, "Narrative Complexity in Contemporary American Television", The Velvet Light Trap, November 58, Fall 2006, p. 29-40. Mittell gives an extremely convincing definition of narrative complexity: "At its most basic level, narrative complexity is a redefinition of episodic forms under the influence of serial narration - not necessarily a complete merger of episodic and serial forms but a shifting balance. Rejecting the need for plot closure within every episode that typifies conventional episodic form, narrative complexity foregrounds ongoing stories across a range of genres", p. 32.

${ }^{8}$ In an interview concerning the main title sequence Scott Boyajan explained: "Our goal was to create a title sequence that grounded viewers in the mid 1930s, but that also allowed
} 
world of Carnivàle as the camera zooms into a deck of Tarot cards immediately gesturing "the viewer toward the occult9" realm of the narrative. As the camera moves into one of the cards ${ }^{10}$, the viewer is transported through a fictional world of paintings ${ }^{11}$, which transitions seamlessly into the real world, denoted by historical footage of the Thirties ${ }^{12}$. The camera then moves back out before entering another card, and so on. The camera's constant oscillation between fiction - the paintings - and reality - the news reels - conveys a sense of confusion among viewers as it questions the boundary between both realms, while the haunting score enhances the hypnotic effect of the opening title sequence ${ }^{13}$

The pilot - Milfay - opens with a prologue told by Samson (Michael J. Anderson), the carnival's dwarf manager. The prologue not only evokes that of J.R.R. Tolkien in The Lord of the Rings (1954) ${ }^{14}$, but immediately captures the viewer's attention as it presents him/her with the plot's narrative framework:

Before the beginning, after the Great War between Heaven and Hell, God created the Earth and gave dominion over it to the crafty ape he called Man; and to each generation was born a creature of light and a creature of darkness; and great armies clashed by night in the ancient war between Good and Evil. There was magic then, nobility, and

people to feel a larger presence of good and evil over all of time", "A52 Masters Fate in New Main Title Sequence for HBO's Carnivàle”, darnellworks.com. September 15, 2003 <http://www.darnellworks.com/a52/nroo52.htm>, April 15, 2011. The influence of Carnivale's opening title sequence can also be traced in the opening title sequence of Showtime's series Huff (2004-2006).

9 David Marc, "Carnivàle. TV drama without TV genre" in It's not TV. Watching HBO in the Post-Television Era, edited by Marc Leverette, Brian L. Ott and Cara Louise Buckley, New York and London, Routledge, 2008, p. 101-107, p. 101.

${ }^{10}$ Each card figures a famous painting, which changes anamorphically into a news reel

${ }^{11}$ Peter Brueghel the Elder's Fall of Rebel Angels (1562) and Peter Brueghel the Younger's

The Peasant Dance (1568), Michelangelo's fresco The Last Judgement, Saint Michael Vanquishing Satan by Raphael, War in Heaven by Hieronymus Bosch (c. 1500), Gustave Doré's The Archangel Michael and his Angels Fighting the Dragon (1865-1866)...

${ }_{12}$ The news reels show historical footage of the Bonus Marchers approaching the Capitol, Mussolini, Roosevelt, Molotov and Stalin, Jesse Owens and Babe Ruth and the Ku Klux Klan.

${ }^{13}$ Hélène Duccini lays emphasis on the importance of music, which signals the switch from reality into fiction in opening title sequences, just in the same way it does in television commercials: "La musique des génériques d'émission joue un rôle analogue [à celui du spot publicitaire]: prévenir les téléspectateurs, peut-être éloignés du récepteur, que l'émission commence ; c'est un signal d'appel. » In Hélène Duccini, La télévision et ses mises en scène (1998), Paris, Armand Colin, 2010, p. 17.

14 Daniel Knauf noted in an interview: "I'm a big fan of Tolkien", in "The Making of a Magnificient Delusion", <http://www.hbo.com/carnivale/behind/daniel knauf.shtml>, April 11, 2011. See also David Knauf's interview by Kate McCallum, « The Great Idea. HBO's Carnivàle », Scriptmag.com, May/June 2004, <http://www.bridgeartsmedia.com/img/ Carnivale.pdf>, April 15, 2011: "I loved The Lord of the Rings. I loved epic fantasy [...]", p. 32. 
unimaginable cruelty; and so it was until the day that a false sun exploded over Trinity, and Man forever traded away wonder for reason.

The close-up on Samson's face, which is accentuated by the dark background surrounding him, highlights the timeless dimension of the epic $^{15}$ informing it with a universal dimension. Immediately after the prologue there is a brief and abrupt flash of light. The viewer is then suddenly plunged into Ben Hawkins's nightmare: a world saturated with cryptic clues and symbols. A detailed study of this nightmare reveals that all the key elements of the series are already present, as Daniel Knauf explains, "for me the thesis was set out at the very first episode ${ }^{16 "}$. Consequently, the viewer is given a number of hints to help him/her wade through Carnivàle's complex narrative maze. Moreover, the economy of the dream segments enabled Knauf to pile up information in a condensed narrative form. There is undoubtedly a Lynchean colouring to this dream segment, which is reminiscent of FBI Special Agent Dale Cooper's surreal "red room dream" in Twin Peaks $(1,3)$. Indeed, as in Dale Cooper's dream in which the evil character of Bob appears through flashes of light, the Tattooed Man, whom we see running through the fields in Ben's nightmare, is glimpsed at through flashes of lightning conferring an almost subliminal effect to the dream's imagery. Consequently, the viewer is left with the impression he/she has just awoken from a nightmare, which he/she only remembers fragmentarily. As Knauf explains, "it's done in flashes, and it's done almost to an abstraction" to "start a clue going17". The dream ends almost as abruptly as it began with Ben waking up in his home. The opening scene of Carnivale clearly mirrors the opening title sequence as we move from the world of fiction (Samson's prologue and Ben's dream) to the tragic reality of Ben's mother's death in a dustridden Oklahoma farm.

The dream and vision segments also enable Knauf to stage the remote battle waged between Ben Hawkins and Brother Justin, laying emphasis on the parallel structure of the narrative. The second episode, After the Ball is Over, opens on Ben Hawkins and Brother Justin's first shared dream from which both characters will awake simultaneously. This brief segment ${ }^{18}$ gives the viewer further information on the show's narrative pattern. We can see Ben and Brother Justin sitting side by

${ }^{15}$ As Gilles Deleuze notes, "the close-up extracts the face [...] from all spatio-temporal coordinates". Gilles Deleuze (translated by Hugh Tomlinson and Barbara Habberjam), Cinema 1 The Movement-Image (1983), Minneapolis, The University of Minnesota Press, 2009 , p. 108.

${ }_{16}$ Daniel Knauf, "Magic and Myth. The Meaning of Carnivàle”, Carnivàle. The Complete Second Series, HBO Home Video, 2006.

17 "Dan Knauf Interview", The Bally, February 15, 2005, <http://wwwcarnycom/bally/dan.html>, April 11, 2011.

${ }_{18}$ The way in which this scene is filmed is reminiscent of the atmosphere depicted in Edward Hopper's painting Nighthawks (1942). 
side at a counter in an empty diner as they are greeted by the waitress's cryptic words "Every Prophet in his House". Facing them is a mirror in which they can both see Henry "Hack" Scudder and Lucius Belyakov. This scene functions as a visual chiasmus in which Scudder, Ben's father ${ }^{19}$, wearing an evening jacket and a top hat, can be seen seated behind Brother Justin while Belyakov ${ }^{20}$, Justin's father, dressed in a Russian uniform, is sitting behind Ben.

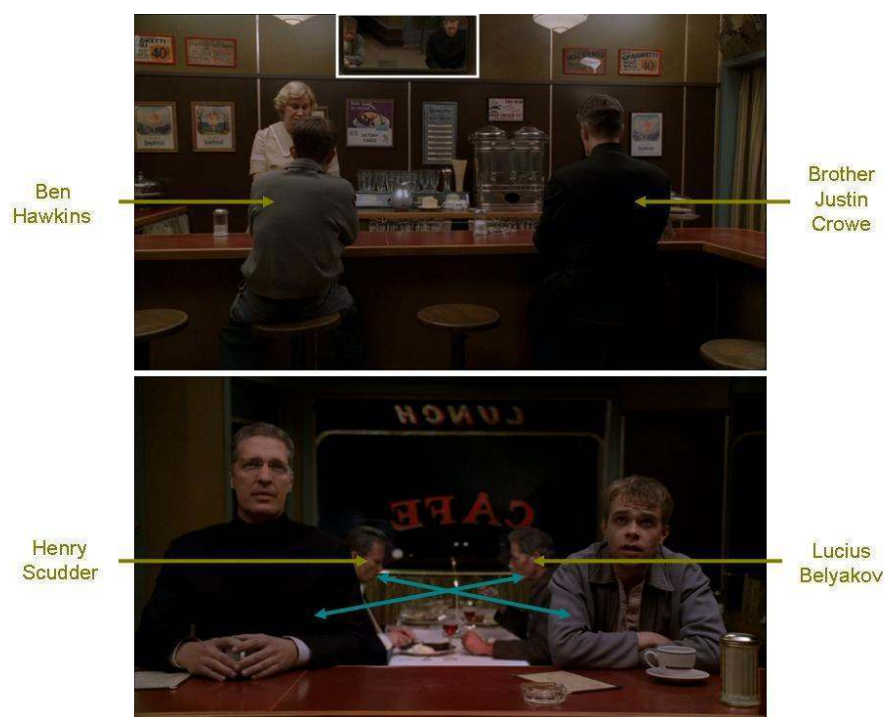

Not only does this scene stress the parallel structure of the narrative, highlighting the forthcoming battle between good and evil, but the visual chiasmus while restoring both Avatars' ${ }^{21}$ ascendancies through the reflection in the mirror, also indicates the double-crossing intrigue and the way in which the parallel plotlines will constantly overlap during the two seasons to finally conflate into a single plotline in which both Avatars will confront one another as prefigured by the final explosion that brutally ends the dream.

In Insomnia (season 1, episode 9) and Hot and Bothered $(1,10)$ Ben is fighting off sleep so as not to have to face his nightmares. In Hot and Bothered, as soon as Ben dozes off, the figure of the Tattooed man reappears before him. Ben's momentary lapses of consciousness denote

${ }^{19}$ Samson tells Ben: "I reckon Henry Scudder is your daddy",The River, season 1, episode 7.

${ }_{20}$ Daniel Knauf notes that Justin and Iris are "the children of Belyakov" in "Magic and Myth. The Meaning of Carnivàle", op. cit.

${ }^{21}$ In the series the Avatars are portrayed as human-like beings with supernatural powers. Each generation gives birth to a Creature of Light and a Creature of Darkness. 
not only the collapsing boundaries between fiction and reality - which are recurrent throughout the show, highlighting the fissures in the narrative pattern - but they also work as signals addressed to the viewer to help him/her remain fully aware of the narrative's unfolding and its significant details.

The dreams and visions function both analeptically and proleptically as they provide links between the different episodes of the narrative, as well as between the past, present and future. A role also embodied by characters such as the carnival's blind mentalist, Lodz (Patrick Bauchau), who acts as a link between the carnies and the Avatars (Management, Ben Hawkins). He will also link the living and the dead in the show's second season notably when he takes over Ruthie's body to communicate with Lila, the Bearded Lady. Yet dreams are also a means to reflect the uncertainty and the fear of the period, as Ruthie, the snake charmer, tells Ben in Hot and Bothered: "Everyone has bad dreams. It's the times we live in. It's hard to feel safe..."

Hence, dreams convey in Carnivàle a sense of doubt and indeterminacy as they become the locus of hidden and mysterious meanings. Yet, by deciphering the dream and vision segments, the viewer will probably enjoy a clearer view of the narrative's cryptic meaning as Lodz tells Ben in Insomnia: "you must listen to what your dreams tell you. They will guide you". A piece of advice which may well be understood here as an oblique address to the viewers.

However, dreams are only one example of the links between the diegesis and the supernatural events which occur regularly throughout the show. In After the Ball is Over $(1,2)$ Clayton Jones, (a.k.a. Jonesy), assigns a task to the roustabouts while he asks Ben to clean the baggage trailer:

JONESY. You're in charge of the baggage trailer.

BEN. The what?

JONESY. Baggage trailer 'round back. Run down trailer with a big ole roof on her. Can't miss it.

Ben obeys and as he walks away from the carnival's encampment he comes to the trailer, which is located under a tree on the outskirts of the encampment. As he enters the trailer he notices a fotus in a jar, he then opens an old case in which he finds an evening jacket, a top hat and an old dusty box, which contains the picture of a young woman standing in front of a truck bearing the "Big Sky Farms" sign. As he looks at the back of the photo he sees the following initials "H. S. [Henry Scudder] and FLO [obviously his mother Flora]". The trailer's door suddenly slams shut, leaving him in the dark, enhancing the underlying tension and unsettling atmosphere of the scene. As he leaves the trailer, the eyes of the fotus open suddenly - "a great 
moment 22 " according to Knauf - warning the viewer about the uncanny and eerie aspect of the story, maybe also a way for the director to tell the viewer: "keep your eyes wide open". When Ben tells Samson he has just come from the baggage trailer, the latter retorts: "We don't got no baggage trailer. Nobody's got a baggage trailer. It's an old carnie gag, like hunting for snipe." When Ben brings Samson to the place where the trailer was it has, to his great surprise, disappeared. But there is an uncanny feeling when Ben shows Samson the photo he found "[i]n the trailer that ain't there".
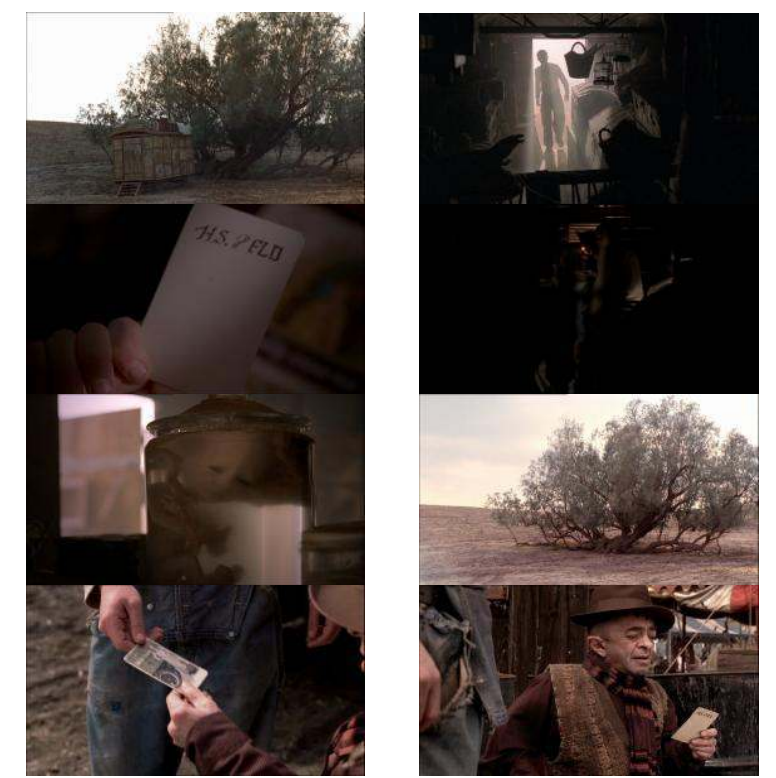

This lapse in the interstices of the narrative fabric illustrates how insignificant objects, which stand for "concrete reality 23 ", induce what Barthes referred to as the Reality Effect. These details convey a sense of realism to the narrative. Ben's photograph illustrates the "need to authenticate the 'real': [as] the photograph [is] ([an] immediate

${ }^{22}$ Daniel Knauf, "Behind the Scenes. The Making Of Carnivàle”, Carnivàle. The Complete First Series, HBO Video, 2004.

23 Roland Barthes, "The Reality Effect" (1968), in The Novel: An Anthology of Criticism and Theory, 1900-2000, edited by Dorothy J. Hale, Oxford, Blackwell Publishing, 2006, p. 229-234, p. 233. 
witness of 'what was here')24", shedding light on the flaws and cracks of reality through which surreal events slip into the narrative, enhancing not only the weird atmosphere which imbues the show, but also the lifelike features which characterize the entire series.

Furthermore, the parallel and circular structures of the narrative pattern carefully tread lines between fiction and reality, enhancing the viewer's puzzlement. The importance of the various opposing groups of characters portrayed throughout the series shed light on the plot's parallel structure as well as on the way in which both plotlines interact: Sofie and Apollonia; Brother Justin and Norman Balthus; Brother Justin and Clayton Jones and Brother Justin and Ben Hawkins, etc. I will only examine here three of these couples.

The relationship between Brother Justin and Norman, who took Justin and his sister Iris in when they were only children and nurtured them, will progressively deteriorate notably because of Justin's deep belief that he has been chosen by God to carry out some mysterious mission. At the beginning of season 2, Norman is left paralysed and mute after undergoing a stroke in Los Moscos (2.1). The stroke was probably caused by the revelation of Justin's true nature. A change in character which occurs during his errand ${ }^{25}$ on the roads of California and his stay at the Sherwood State Hospital's psychiatric ward: "Justin Crowe, the man, died in the wilderness". Not only does Norman act as the revealer of Justin's true nature - "my greatest evil: saving your life!" - but he is there to witness the event of the Creature of Darkness within Justin ("Justin there is a demon within you", The Day that Was the Day (1.12). Yet he is unable to kill him in cold blood when Justin pleads with him to do so, and as such he remains Justin's "last link to humanity ${ }^{26}$ ". It is only when Justin fully reveals his evil nature that Norman will try to assassinate him during one of the preacher's public rallies (Lincoln Highway, UT, 2.9,). Norman's failure to kill Justin, the Usher of Destruction ${ }^{27}$, may illustrate, in a certain way, man's inability to prevent the Armageddon.

\footnotetext{
${ }^{24}$ Ibid.

25 Brother Justin, "I have journeyed into the wilderness", 1, 10. In the same episode Brother Justin is filmed walking down the church's central aisle revealing some of the darkest secrets about certain members of his congregation. This scene seems to echo ABC's miniseries Storm of the Century written by Stephen King and produced in 1999. The evil character, Andre Linoge (anagram of the demon Legion), is seen walking slowly up the church aisle revealing the town folks' darkest secrets, creating havoc within the island's small community.

${ }^{26}$ Michael Strang, Fan and Carnivàle mythologist in "Magic and Myth. The Meaning of Carnivàle", op. cit.

${ }^{27}$ In the mythology of Carnivàle, the Omega is, like the Alpha, a female who is the only other known exception to the male restriction in Avatar succession and because of the allusion to "the Beginning and the End" in naming, the Omega is commonly accepted as the last Avatar. The Usher of Destruction is a harbinger of the End of Times to usher in the Armageddon.
} 
Although both characters do not meet during the first season, the personal evolution of Brother Justin and Jonesy clearly contribute to emphasize the narrative's parallel structure. Halfway through the first season in Pick a Number (1.6), Brother Justin loses his faith in God after the mysterious fire that destroyed Chin's brothel killing six homeless children, and decides to leave Mintern. While sitting one evening with a group of hobos around a campfire he tells the undercover reporter Tommy Dolan: "I lost my God". This episode signals his progressive switch over to the "dark side of the Force". Meanwhile, Jonesy loses his faith in Samson, having discovered while visiting Management's trailer (Black Blizzard, 1.4) that there was no one behind the curtains. The segment's chiaroscuro lighting establishes a visual tension enhanced by the haunting score, while the contrasting interplay between light and dark signal the uncertainty and ambiguity of the scene warning the viewers against any reliance on what they and Jonesy see.

The parallel structure is also enhanced by the Doppelgänger motif and the recurrent use of mirrors. In Los Moscos (2.1) Sofie is filmed from behind, wandering all alone on a dusty road. The viewer catches a glimpse of two shadows stretching behind her and walking side by side: Sofie's and that of a female veiled figure, whom we suppose to be her mother. In the final episode, Sofie, who is locked up in the cabin off Brother Justin's house, confronts a black female figure dressed in a funeral veil whom the viewer believes once more to be Apollonia. As the figure nears Sofie, she lifts up her veil revealing not Apollonia's face but Sofie's who tells her "This... is... your... house": thus giving shape to the cryptic sentence "Every Prophet in her House" uttered to Sofie by a young girl she passes by as she is walking along the road leading her to New Canaan (The Road to Damascus, 2.6). This scene is a perfect illustration of the show's puzzle-like pattern in which all the pieces seem to fall into place retrospectively.

While discussing the two main protagonists, Daniel Knauf argued that Ben "[is] the mirror image of Brother Justin ${ }^{28}$ ". This is perfectly illustrated in the peeling scene in Alamogordo, $N M$ (2.2), when Brother Justin has one of his visions while combing his hair in front of a mirror. The comb suddenly sticks and yanks a piece of flesh from his scalp. Another piece comes and another, until his entire face is peeling off as he finally shreds the mask of skin from his head revealing Ben Hawkins's face. "Who are you?" asks Justin while gazing at the ghoulish sight. This segment is a nod to Lynch's TV series, notably the episode (Lonely Souls, 2.14) in which Leland Palmer, while looking at himself in the mirror, sees the reflection of Killer Bob's face - the

${ }^{28}$ Daniel Knauf, "Magic and Myth. The Meaning of Carnivàle”, op. cit. 
demonic entity hosted in Leland's body - smirking back not really at him but at the viewer.

Another main feature of the narrative lies in its circular pattern. If we consider the first (Milfay) and last episodes (New Canaan, CA) of the show, we cannot avoid noticing the obvious circularity of the plotline. The close of the first episode ends with Ben healing Maddy, the young disabled girl. While performing his cure on the young girl's legs the surrounding nature withers of life, the flower petals fall, the grass wilts and blackens progressively. To cure the little girl, Ben has had to sacrifice the surrounding nature ${ }^{29}$. This scene is mirrored during the show's final cliffhanger as we see Sofie entering the cornfield. As she begins healing Brother Justin the surrounding corn ears blacken and wither progressively row after row. The circular pattern of the narrative tends to corroborate Chris Albrecht's claim that the second season of Carnivàle was to end so as to propose a satisfactory close-ended conclusion to the viewers and it seems, therefore, possible to believe that the series' creator, who introduced the cliffhanger, was hoping to pressure HBO into pursuing the show ${ }^{30}$.

As a result, we may note how both the holistic dimension and fragments of the narrative convey a puzzle-like impression to the show. The fragments and the overall framework are closely intertwined; as Daniel Knauf explains, "[i]f you're going to deconstruct the show, you have to start from the big and work your way down to the small31". Each episode plays, just like in a puzzle, a pivotal part in the overall structure as each detail contributes to the depiction of the whole picture, suggesting a more dynamic role of the viewer. However, Knauf warns us against reading too much into the show: "like I said [...] sometimes a cigar is just a cigar ${ }^{2}$."

\footnotetext{
${ }^{29}$ Ben is told by Management in The Day that Was the Day $(1,12)$ : "To restore a life, you must take a life... That is the way of our kind."

30 "Albrecht tells reporters that the second season of Carnivàle was originally supposed to conclude with a satisfying and close-ended conclusion [...] but that producers decided to add a cliffhanger, leaving the show's small, but passionate legion of devotees at a loss", "Carnivàle Fans Besiege HBO with E-mails", ZAP 2 it, July 19, 2005. Yet, in an interview, Daniel Knauf notes that he understood Chris Albrecht's decision; see "Dan Knauf Speaks about Carnivàle's Cancellation", Wednesday, May 11, 2005. <http://savecarnivale. blogspot.com/2005/o5/dan-knauf-speaks-about-carnivales.html>, April 11, 2011. There is another piece of evidence underscoring the circular structure of the narrative. During the first episode Jonesy seats Maddy and her brother in the Colossus Ferris Wheel and in the final episode he will make sure that both Iris and Justin are firmly seated in the wheel. This could possibly be read as parable of the fall from innocence (childhood) to sin (adulthood), from the Age of Wonder to that of Reason. This is corroborated by the fact that the atomic bomb also stands for a metaphor of this dramatic change, as Daniel Knauf explains, "[t]hat event marked the end of man as a child. That's when man entered his adulthood".

31 "Dan Knauf Interview", The Bally, February 15, 2005. <http://www. Carnycom/bally/dan.html>, April 11, 2011.

${ }^{2}$ Ibid.
} 
Hence, the eruption of dreams into waking experience transgresses the limits between dreams and narrative reality as it refers to a reality located beyond the limits of dreams conveying a feeling of otherworldliness. By disrupting the linearity of the narrative process, the dreams and visions introduce an unstable verisimilitude, which not only puzzles the viewer, but leads him/her to the discovery of an apparently unknown reality. Moreover, the binary and circular patterns of Carnivàle's narrative deviate from the traditional narratological canons, greatly contributing to the show's constant interplay between fiction and reality. Another prominent aspect of Carnivàle I wish to explore now is the way in which Daniel Knauf wove fiction into historical reality by notably altering historical chronology, creating once again confusion and disorientation as the narration manipulates time and space.

\section{Historical realism and fiction in Carnivàle}

Carnivàle is set at the core of the Great Depression and the Dust Bowl; Daniel Knauf claims he chose that particular historical period because "the Depression just seemed such a pivotal time in American history when anything could have happened and there were so many awful things happening back then. It seems almost a reasonable [...] proposition that the devil was there 33". I shall therefore delve into the way in which the storyline is embedded into history and examine how both are intricately interwoven. The historical setting 34 depicting America amid the throes of the Depression contributes to the portrayal of a period of despair, war fears and political tensions. Furthermore, setting the plot in the past clearly gives an impression of remoteness 35 while contributing to its epic dimension.

The historical template of the plot comprises a period going from the First World War to the Trinity Test, which took place on July 161945,210 miles south from Los Alamos on the Alamargodo Bombing Range. The recurrent visions of the trenches in which Henry Scudder crosses paths with the Russian infantryman Lucius Belyakov, an opposing Avatar, may well be viewed as an omen of the Second World War, which will reach its climax with the use of the atomic weapon. While their encounter heralds the forthcoming battle between their offspring - Ben Hawkins and Justin Crowe - the nuclear

33 Daniel Knauf in "The Museum of Television \& Radio's William S. Paley Television Festival. Carnivàle”, March 16, 2004, in Carnivàle. The Complete Second Series, op . cit. 34 The historical setting of Carnivale required significant research and the presence of a historical consultant who greatly contributed to reviews praising the show's depiction of the period.

35 Daniel Knauf explains that he "wanted to do something with the aspect of more long ago and far away. I think [the show] would have lost a certain amount of its mystique if it were [set in the present]", Scriptmag. Com, op. cit., p. 33 
explosion Ben envisions in his dreams, in $\operatorname{Los} \operatorname{Moscos}(2,1)^{36}$, not only symbolizes the Apocalypse, "[a] weapon, a full sun wrought by the hands of men. It is the last link in a chain of events unfolding even as we speak [...] 37 " but also marks the end of the Age of Wonder and the beginning of the Age of Reason mentioned by Samson's prologue.

I will, therefore, chart out how the historical context of the depression and the Dust Bowl, the numerous cultural references, the radio and the circus all partake in creating the subtle cultural and historical subtext of the series. However, the chronological and geographical discrepancies question the show's realism.

From the outset the atmosphere of the period informs the show. As Ben Hawkins is about to bury his mother, who has just died of dust pneumonia, a bulldozer moves into the frame. Ben steps in between his mother's body and the bulldozer, frantically trying to prevent the destruction of his home, but the driver tells him he has been appointed by the bank to expropriate him and destroy his farm: "This is the property of First Merchants Trust. Now you've been warned. Law's on its way." Because of the Great Depression many farmers failed instalment payments as a consequence of which banks repossessed their farms throwing them and their families onto the roads in search for a better life. This type of situation was, at the time, an everyday occurrence. Numerous stories recount similar dramatic cases. One example is to be found in Studs Terkel's book, Hard Times (1970):

One morning a giant tractor came in, like we had never seen before. My daddy used to do all his work with horses. So this huge tractor came in and began to knock down this corral, this small corral where my father kept his horses. We didn't understand why. In the matter of a week, the whole face of the land was changed [...]. We all of us climbed into an old Chevy that my dad had. And then we were in California, and migratory workers ${ }^{3}$.

Meanwhile, the side show caravan appears and the carnies, who will pick up Ben, help him bury his mother. This particular scene underlines the sense of mutual aid, which, according to some of

\footnotetext{
${ }^{36}$ See this segment on YouTube, <http://www.youtube.com?v=WSLFXzjhEM8>, January 10, 2012.

${ }_{37}$ Management to Ben in Los Moscos 2.1).

${ }^{38}$ Studs Terkel, Hard Times. An Oral History of the Great Depression (1970), New YorkLondon, The New Press, 2005, p. 53. See also of course The Grapes of Wrath: "The tractor cut through again; the uncut space was ten feet wide. And back he came. The iron guard bit into the house-corner, crumbled the wall, and wrenched the little house from its foundation so that it fell sideways, crushed like a bug. And the driver was goggled and a rubber mask covered his nose and mouth. The tractor cut straight line on, and the air and the ground vibrated with its thunder. The tenant man stared after it, his rifle in his hand. His wife was beside him, and the quiet children behind. And all of them stared after the tractor." John Steinbeck, The Grapes of Wrath (1939), New York-London, Penguin Books, 2006, p. 38-39.
} 
Terkel's witnesses, has disappeared nowadays 39 . The ubiquity of poverty at the time is made clear from the very first episode of the series as we see Ben walking along the railroad tracks where the poor migrants have set up their encampment recalling the photos taken, at the time, by Dorothea Lange ${ }^{40}$ who chronicled the lives of the migrants and displaced people during the Dust Bowl.

In the fourth episode entitled Black Blizzard, the Dust Bowl is the main character of the plotline and bears a strong resemblance to the description of the storms in the opening chapter of The Grapes of Wrath ${ }^{41}$ and in Woody Guthrie's song entitled The Great Dust Storm (Dust Storm Disaster) ${ }^{42}$ in which he portrays the storm which occurred on April 141935 .

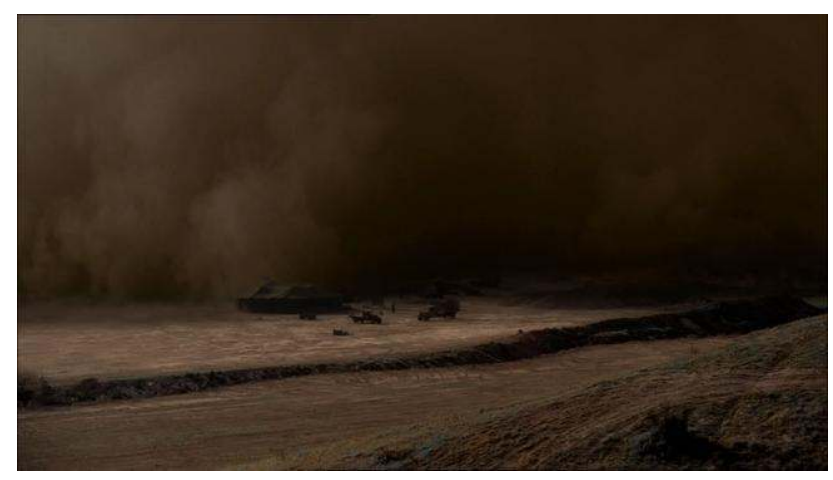

Because of the storm, the protagonists are held in camera, therefore inducing moments of great tension creating at times a stifling and claustrophobic atmosphere as is the case for the trio: Samson, Osgood and the prostitute, Miss Jolene. Not to mention the duo: Lodz, the blind mentalist, and Ben Hawkins who find refuge from the storm

${ }^{39}$ Studs Terkel, op. cit.: "I think the Depression had some kind of human qualities with it that we lack now", p. 53; "The farmers were almost united. We had penny auction sales. Some neighbour would bid a penny and give it back to the owner", p. 218.

$4^{40}$ See Pierre Borhan, Dorothea Lange. Le cœur et les raisons d'une photographe, Paris, Éditions du Seuil, 2002, p. 54 et p. 94. See also Studds Terkel, op. cit., "Here were all these people living in old, rusted-out car bodies. I mean that was their home. There were people living in shacks made of orange crates. One family with a whole lot of kids were living in a piano box. This wasn't just a little section, this was maybe ten-miles wide and ten-miles long. People living in whatever they could junk together", p. 51.

41 "The wind grew stronger, whisked under stones, carried up straws and old leaves, and even little clods, marking its course as it sailed across fields. The air and the sky darkened and through them the sun shone redly, and there was a raw sting in the air", John Steinbeck, op. cit., p. 2. See also Studs Terkel, op. cit.: "Oh, the dust storms, they were terrible [...]. These storms, when they would hit, you had to clean house from the attic to ground. Everything was covered in sand. Red sand, just full of oil”, p. 46.

$4^{2}$ Woody Guthrie, Country \& Folk Roots, London, Sanctuary Records Group Ltd, 2003. 
in an abandoned house. Lodz takes advantage of the situation to test Ben's powers. For others the storm provides a moment of rest and relief as it does for Sofie and Harlan, the café owner. Yet the Dust Bowl may also be read as something supernatural and viewed, from a religious viewpoint, as a punishment from God, which is exactly how Brother Justin views it in Milfay:

Latter days version of the vile plagues that rained on Egypt, the fires that consumed Sodom and Gomorrah, scourges of the Old Testament, yes, but even now brothers and sisters, even now, droughts and pestilence fester in the very heart of this great land [...] Titanic sandstorms, the likes of which man has not seen since the days of the prophets. And I ask myself, what are these things? What are they if not evidence of God's fury? What are they if not harbingers of the Apocalypse?

A network of cultural references also contributes to conveying the atmosphere of the Thirties enhancing the show's realism. The names of Theda Bara, Caruso, Dempsey, Valentino and Bela Lugosi mentioned by Samson and Jonesy are all evocative of the period.

Some historical events are mentioned now and then during the show. In Babylon, Lila, the Bearded Lady, reads the newspaper headlines to Lodz and informs: "Austrian Chancellor, Engelbert Dolfuss, was assassinated last night by nazi insurgents" - consequently locating the events in July 1934. In Alamogordo, $N M(2,2)$ the camera lingers on one of the roustabouts sleeping, his face covered by The Daily Chronicle whose headlines inform us of the Italian annexation of Tripoli, also situating the action in 1934 . But in Creed $(2,5)$, while arriving at their destination the rousties are discussing the upcoming "fight of the century" between Joe Louis and Max Baer in September 1935. Thus, while these historical events anchor the fictional narrative into historical reality, by distorting them so they fit the narrative pattern, the producer blurs once more the boundaries between fiction and reality. Yet, while fictionalizing history the show creates its own fictional reality.

The other main feature of the series I would now like to dwell on is the radio. The radio was a social and cultural force which dominated America in the Thirties, a period which has often been referred to as the "Golden Age" of radio. As Robert J. Brown notes, by "the mid1930 [the] radio became a pervasive influence in American life 43 ". The radio's great popular appeal was partly due, as Matthew Teorey avers,

43 Robert J. Brown, Manipulating the Ether. The Power Of Broadcasting Radio in Thirties America, Jefferson, North Carolina and London, McFarland \& Company, Inc., Publishers, 2004, p. 2. My study owes much to Robert J. Brown insightful study on the major influence of the radio during the Thirties in America. 
to the fact that "its fictional characters entered the listener's world44" in the same way that, nowadays, the heroes of Carnivàle enter our own world. Hence, while contributing to what Barthes termed the Reality Effect, the radio will also provide for the show's meta-fictional aspect.

Although the radio played a major role in making the country more homogeneous, it was also used by some as a pulpit to spread venom throughout the ether. So, despite the atmosphere it contributes to creating throughout the show notably by playing Ruth Etting's song "Love $\mathrm{Me}$ or Leave $\mathrm{Me}$ " as well as music by Duke Ellington, Cab Calloway and Tommy Dorsey, it is used as a pivotal element of the show's narrative structure. In Milfay the radio denotes the contrapuntal function of objects in fiction as it provides us with a narrative counterpoint to Brother Justin's nightmare. As Justin awakes, the radio is broadcasting the famous radio show The Shadow, and we can hear the popular radio character addressing his opponent, Joe Brecker, a convict who is about to be executed: "So you weren't expecting me, and yet prisons are filled with shadows, shadows in the minds of men walking in the shadow of death itself." Brother Justin, like The Shadow's foe, is a prisoner of his own dreams and visions, which recurrently come to haunt him at night, bestowing upon his shadowy character an aura of mystery. It is, however, worth noticing here again the anachronistic feature of this scene. The Shadow was a famous radio show all throughout the Thirties. However, the episode used in this short segment is entitled The Silent Avenger 45 , and was broadcasted on March 13, 1938. Yet, Carnivàle is supposed to take place in 1934. This throws light once more on the way in which the authors manipulate and distort historical facts to suit the narrative pattern.

During his errand as he wanders the roads of California Justin will become the hero of a radio show entitled True Tales on the Road, a show produced by Tommy Dolan on KZAK radio station. The radio creates a mise en abyme effect in the narrative structure, as the fictional character of Brother Justin becomes the hero of a fictitious show within the diegesis. His errand is punctuated by the recurrent question raised at the end of each broadcast: "And what about Brother Justin? Where is he? Where are you, Brother Justin?” This mise en abyme effect is enhanced in Pick a Number (1.6). As we hear Tommy Dolan's recurrent question, an old garage owner is sitting listening to the radio. Meanwhile, the viewer sees through the open garage doorframe Brother Justin walking by in the distance and disappearing

\footnotetext{
44 Matthew Teorey "Metadrama in Old Time Radio: 'Abbott...What Page Are You On?”, The Journal of American Culture, Volume 34, Issue 4, December 2011, p. 357-371, p. 357. 45 The mp3 recording of this programme can be found on the following website: <http:// www.oldradioworld.com/Shows/The_Shadow.php>, March 11, 2011.
} 
into the night, signalling to the viewer the beginning of his dark and solitary errand into the wilderness.

In Hot and Bothered (1.10) Iris convinces her brother of the fantastic potential of the radio: "100,000 people listen to his show every week and those listeners could be the backbone of your new church", while Dolan insists on the great advantages he could have spreading his word thanks to the new medium: " 30 million people have radios in this country Brother Justin. It's a new age." It is to be noted that his programme is an evening show: as Robert J. Brown argues, while discussing the reason for which Orson Welles's broadcast "War of the Worlds46" was so conclusive in inciting panic among the listeners, "tuning late was a strong conditioning factor 47 ".

Therefore, at the end of the first season and all during the second one the radio will become the instrument through which Brother Justin will mould and manipulate people's minds, underlining the major influence of the medium in the Thirties. Franklin D. Roosevelt was probably the first American politician to recognize the radio's full potential 48 notably through his "fireside chats" as the medium gave him direct access to the people. Yet Roosevelt was not the only talented radio orator who understood the power of the new medium. Such was also the case of one of America's most potent radio demagogues, the so-called Radio Priest, Father Charles Edward Coughlin, who greatly inspired the character of Brother Justin. The radio progressively becomes the medium through which Justin will manipulate minds and convert his flock of listeners to his cause with his religious evening programme: Brother Justin's Church of the Air 49 . The radio's potent influence is illustrated by the way in which Justin enrols Varlyn Stroud - Los Moscos (2.1) - who is in prison, while his radio show is being broadcasted. We hear Justin's voice in a subliminal message call on Stroud - "You will be my apostle" - as he sets him free, a way of demonstrating the radio's hold over the listeners and the power exerted by those who mastered that medium.

Let us now consider Brother Justin's rhetoric in his fire-andbrimstone sermons. Justin's rhetoric owes much to that of Roosevelt who would routinely refer to himself in the first person and address the American public as "you" allowing for his words to come over as a friendly conversation ${ }^{\circ}$ conveying a sense of close interaction with the

\footnotetext{
46 The programme was broadcasted in the evening on October 30, 1938

47 Robert J. Brown, op. cit., p. 238.

${ }^{4}$ For a more detailed study on Roosevelt's use of the medium see Robert J. Brown, op. cit. 49 We may perhaps draw a parallel here between the character of Brother Justin who claims to be "the left hand of God $[\ldots]$ I am no longer his servant" $(1,8)$ and the main character of Flannery O'Connor's novel Wise Blood, Hazel Motes, whose church "is the Church Without Christ”. Flannery O'Connor, Wise Blood (1952), London, Faber and Faber, 2008. ${ }^{\circ}$ Ibid., p. 18
} 
public: "And though I am alone in this studio I can sense your presence. You are with me and I am with you" (Los Moscos, 2.1).

Yet, the rest of his speech clearly recalls the rhetoric and themes developed by Father Coughlin whose speeches mingled politics and religion which would rivet public attention by creating what Donald Warren terms "an ecumenism of discontent 51 ": "This land, your land, has been stolen. Stolen by the international bankers. Stolen by the crooked politicians. Stolen by cheap immigrant labour" (Los Moscos, 2.1). This sermon clearly echoes some of Father Coughlin's: "Keep America safe for Americans and not the hunting ground of international plutocrats!52"; "the international bankers of ill repute53", which highlight both features of anti-semitism and populism. Both Roosevelt54 and Coughlin had outstanding voices, which proved a significant asset for an aural medium like the radio. Yet, Justin's warm, enthralling and mesmerizing voice, which has an almost sexual tone to it, seems closer to that of Coughlin's than of Roosevelt's. Donald Warren quotes the writer Wallace Stegner's detailed description of Father Coughlin's voice in 1935:

A beautiful baritone... his range was spectacular. He always began in a low rich pitch, speaking slowly, gradually increasing in tempo and vehemence, then soaring into high and passionate tones... His diction was musical, the effect authoritative.

Hence, the character of Brother Justin, who will progressively ensnare the impoverished masses in his spiritual web as the plot unfolds, stands as a subtle blend of two major historical figures of the Thirties - Franklin D. Roosevelt and Father Coughlin - emphasizing once more the interplay between fiction and reality.

The last aspect I would like to focus on is that of the circus which had, as Sofie tells Ben, an important role to play at the time: "The people in these towns, they're asleep. All day at work, at home, just sleepwalkers. We wake them up55" (Milfay). The circus motif symbolises illusion. While illusion is conjured up for the circus

${ }^{51}$ Donald Warren, Radio Priest. Charles Coughlin the Father of Hate Radio, New York, The Free Press, 1996, p. 29.

${ }^{2}$ Ibid., p. 63. This is an excerpt of a speech given on January $27,1935$.

53 Ibid., p. 60. Coughlin was the first to coin the word "banksters", p. 54

54 See Brown, op. cit., "Sam Rosenman admired the 'attractiveness' of his voice; its fine shadings and nuances, [and] the infinite variety he knew how to give it - strength, sarcasm, humor, volume, charm, persuasiveness", p. 20.

55 Knauf was vying for creating a new form of television viewing in which the viewers would involve themselves in the ongoing process of the story. See "Freaking Hell", December 16, 2004, in which Knauf argues that "[a]udiences are just starving for something different. If we think about sleepwalkers, there's sleepwalker TV [...]”, <http://www.theage.com.au/ news/TV--Radio/Freaking-hell/2004/12/ 14/1102787083353.html>, April 11, 2011. 
spectator, this illusion rests on the following paradox: to be effective it must be denied yet considered real in itself. Thus (like the circus spectator) the viewer, while escaping into the realm of illusion, must accept the show's deceptive illusionary totality. The way in which Knauf mingles historical and fictional reality in Carnivàle subtly outlines this tacit agreement between the producer and the viewers.

As Fox and Parkinson note, excitement and anticipation permeated the towns and cities when sideshows or circuses would arrive in town ${ }^{56}$, "coming from nowhere and vanishing into nothing57", while time would be suddenly set in abeyance as a world of fantasy and illusion sprung up into the real world. As Janet M. Davis contends: "[d]uping was a central part of the circus; consequently audiences were always vulnerable as they unwittingly became part of the "show'58", establishing, therefore, a link between the audience and the show.

The way in which the sideshow, and particularly the ten-in-one (Milfay, 1.1), is shot by hand-held camera suggests unrehearsed filming of reality and conveys an impression of dizziness and disorientation. The audience feel as though they are part of the scene rather than viewing it from a detached and remote position, which contributes to engulfing the viewer in a world of confusion and doubt, hence entrapping him/her in the carnival's spider web symbolized by the Colossus Ferris Wheel just in the same way it eventually ensnares Brother Justin 59 .

The sideshow also encompasses the themes of errand, estrangement, alienation and marginality ${ }^{60}$. The eerie and murky atmosphere of the series focuses on the dark side of the human experience. The mysterious Management, the real freaks (Samson and Sabina the Scorpion Woman) and the fake ones (Turtle Boy and The Man Eating Chicken ${ }^{61}$ ), contribute to the show's unsettling atmosphere while inviting the viewer to reflect on human nature.

${ }^{56}$ Charles Philip Fox and Tom Parkinson, The Circus in America (1969), Santa Monica, Hennessey + Ingalls, 2002, p. 10-21.

57 Janet M. Davis, The Circus Age. Culture and Society under the American Big Top, Chapel Hill \& London, The University of North Carolina Press, 2002, p. 45.

${ }^{8}$ Ibid., p. 27-28.

59 Lincoln Highway, UT (2.9) opens as we see Brother Justin looking straight ahead at a spider web sparkling with droplets of water. The web progressively materializes into the carnival's Ferris Wheel as the centre of the web/Wheel glows. An obvious ill omen as Justin's brutal awakening attests to. The Ferris Wheel also symbolizes the magical atmosphere of those kind of fairs.

${ }^{60}$ Davis explains that, at the time, a lot of the circus people "were social outsiders", op. cit.

p. 26.
${ }_{1}$ The Man Eating Chicken plays on the double-entendre of the expression illustrating carny promotional strategy: as the curtain is drawn the viewers discover a man eating chicken. See Lonnigan, Texas (1.8). 
If the show ${ }^{62}$ inevitably brings to mind Tod Browning's famous movie Freaks (1932), the oneirological, dark and disturbing atmosphere reminds us of two other of Browning's movies: The Unholy Three (1925) and The Show (1927). In The Show the persuasive voice of Cock Robin, the spieler of the Hungarian freak emporium called The Palace of Illusions, draws the crowds to his bally stand while their insatiable curiosity keeps the tents filled. Most of the attractions are fake freaks, especially women with lower-body anomalies: Arachnadia the human spider, Neptunia the phony mermaid and Zela the truncated half-girl. The sideshow's main attraction depicts Salome's dance of the seven veils, which reminds us of the Cooch show performed by the Dreiffus women in Carnivàle.

If the sideshow is fraught with references to the fictional world created by Tod Browning, it is also rooted in historical reality, giving once more credibility to the diegesis. Fox and Parkinson argue that the "truck shows ${ }^{63}$ " first appeared in 1918, almost at the time when Henry Scudder found refuge with the Hyde \& Teller Co. travelling circus (Insomnia, 1, 9), when Management bought it out - "just after that Scudder took the power" (Samson, 1.9). Consequently, the roving circus becomes the means through which Belyakov begins trailing Scudder. With its capacity to move about, the sideshow has complete freedom: "the truck circus was free to go as it chose 64 ", making "the country a chess board, [as it] move[d] [its] attractions from one point to another ${ }^{65}$ ". However, as soon as Ben arrives on the scene, the sideshow's circuit is disrupted:

BEN. Do you have a regular circuit?

JONESY. Circuit?

BEN. Yeah.

JONESY. Used to. Now it's just town by town, catch as catch can, and that ain't hardly nothing!

BEN. Since when?

JONESY (a beat). Since you showed up.

A point confirmed, in the same episode, by Lodz who tells Samson: "The circuit's just an excuse. You know that" (Tipton, 1.3).

\footnotetext{
${ }^{62}$ David J. Skal and Elias Savada note that "[f]reakishness, deformity, and disability had taken root as a staple of American entertainment in the years following World War I”, in David J. Skal and Elias Savada, Dark Carnival. The Secret World of Tod Browning. Hollywood's Master of the Macabre, New York, Anchor Books, 1995, p. 89.

${ }_{63}$ Charles Philip Fox and Tom Parkinson, op. cit., p. 165.

64 Ibid.

${ }^{65}$ Janet M. Davis, op. cit., p. 41.
} 
Thus, although the plot is embedded within history, the topographical and geographical reality is of utmost importance ${ }^{66}$, as Daniel Knauf explains: "I had to take something logical and figure out the topography and in venturing into the unknown as they move from one 'crappy little town' $[. . .]^{67}$ " to another. By anchoring the narrative into spatial and territorial reality, Knauf enhances the plot's credibility.

Fourteen episodes out of 24 bear either a geographical indication or the name of a real or fictitious town (Milfay, Tipton, Babylon, The River, Lonnigan, Los Moscos, Alomogordo, Ingram, Creed, Damascus, Lincoln Highway, Cheyenne, New Canaan), underlining the importance of space while also mirroring the oscillation between wilderness, small towns and the open space. Indeed, most of these towns are either like Milfay (Oklahoma) a small unincorporated community, or like Babylon an eerie Texas mining ghost town ${ }^{68}$, which the Navarro county maps do not even show and which is located on an unnumbered county road somewhere between Dawson and Purden, or Cheyenne (another Texan ghost town). Other towns like Creed are not even mentioned on any map of Oklahoma. New Canaan, the carnival's final destination, is a small town located in San Benito County, south of Salinas. One soon gets lost in this geographical maze 69 and begins to lose track of the route followed by the wandering sideshow as it becomes impossible to map the space represented by the lines and nodes of the towns, which appear and disappear in the fissures and fault lines of the landscape. Yet, when the sideshow reaches Lincoln Highway (Lincoln Highway, UT, 2, 9) the unfolding of events suddenly picks up speed, accelerating the narrative's rhythm as both plotlines finally merge.

To conclude, the narrative reality of Carnivàle is filled with cracks and flaws through which surreal and mysterious events find their way, disrupting the narrative pattern yet enhancing its complexity, leaving the viewer at times disoriented and dazzled. While embedding fiction into the historical template of the Thirties, Daniel Knauf deliberately adds a layer of confusion as he distorts and conflates the chronological course of events. Hence, while the realms of

\footnotetext{
${ }^{66}$ Brian Jarvis underlines the link between geography and history in postmodern American culture: "Given the structural inseparability of space/place/landscape and social relations there can be no geographical knowledge without historical narrative. In other words, all spaces contain stories and must be recognised as the site of an ongoing struggle over meaning and value", in Brian Jarvis, Postmodern Cartographies. The Geographical Imagination in Contemporary American Culture, New York, St Martin's Press, 1998, p. 7. ${ }_{67}$ Daniel Knauf in an interview, "Something Cryptic this Way Comes", by Pam Casellas, The West Australian, Perth, December 15, 2004.

68 The only living creatures the carnies meet in Babylon, Stangler, tells them "there's a lot of souls in Babylon".

${ }^{69}$ However, the only clear geographical indication is that of Lincoln Highway also known as the "Main Street Across America".
} 
history and fiction collide, "The Grapes of Wrath meets David Lynch"70.

Like $O Z$, The Wire, or John from Cincinnati, Carnivàle is a perfect illustration of HBO's Golden Age. This hybrid show whose themes and numerous subtextual references may have seemed surprising at first clearly corresponds to what critics have termed "quality television ${ }^{71}$ ": the cinematic quality, the costumes, the detailed historical reconstruction but especially its intricate narrative structure in which fiction subtly melds into reality, "demanded an intertextual literacy and activeness not typical of television viewers ${ }^{72}$ " which contributed to the making of a true work of art. Carnivàle contributed to the advent of new type of viewer which Pierre Bourdieu ironically defined as a kind of "post-modern hermeneutist73".

$7^{70}$ Daniel Knauf, "The Making of a Magnificient Delusion", op. cit.

${ }^{71}$ See Jane Feuer, "The MTM Style". Feuer gives an insightful definition to what is implied by the expression "quality television": "Intertextuality and self-reflexivity operate both as the normative way of creating new programmes and as a way of distinguishing the 'quality' from the everyday product.” In Jane Feuer, Paul Kerr and Tise Vahimagi (eds.), MTM "Quality Television", London, British film Institute Publishing, 1984, p. 32-6o, p. 44.

${ }^{72}$ Brian L. Ott, "Introduction: The not TV text", in It's not TV. Watching HBO in the PostTelevision Era, op. cit., p. 97-100, p. 98.

73 Pierre Bourdieu, Contre-feux. Propos pour servir à la résistance contre l'invasion néolibérale, Paris, Éditions Raisons D’Agir, 1998, p. 84. 